\title{
酸化物/高分子微小球複合グリーンシートからの高分子抽出による チタン酸ストロンチウムセラミックフォームの作製
}

\author{
川崎兼司・尾崎義治 \\ 成蹊大学工学部工業化学科, 180 武蔵野市吉祥寺北町 3-3-1
}

\section{Preparation of $\mathrm{SrTiO}_{3}$ Ceramic Foam from Alkoxide-Derived Oxide Green Sheets Containing Polymer Microspheres via Polymer Extraction}

\author{
Kenji KAWASAKI and Yoshiharu OZAKI \\ Department of Industrial Chemistry, Faculty of Engineering, Seikei University, 3-3-1, Kichijoji-kitamachi, Musashino-shi, Tokyo
}

\begin{abstract}
Preparation of $\mathrm{SrTiO}_{3}$ ceramic foam from alkoxide-derived oxide green sheets containing polymer microspheres via polymer extraction has been studied. $\mathrm{SrTiO}_{3}$ suspension in aqueous media was prepared by hydrolysis of $\mathrm{Sr}\left(\mathrm{OC}_{3} \mathrm{H}_{7}{ }^{i}\right)_{2}$ and $\mathrm{Ti}\left(\mathrm{OC}_{3} \mathrm{H}_{7}{ }^{i}\right)_{4}$. Polystyrene microspheres and PVA (poly (vinyl alcohol)) were added to this suspension (weight ratio: $\mathrm{SrTiO}_{3} /$ polystyrene/PVA=100/60/8), and then precursor green sheets were produced. Polystyrene microspheres were incorporated in the $\mathrm{SrTiO}_{3}$ matrix phase in this green sheets. The polystyrene microspheres were extracted with organic solvent from the green sheets before the heat treatment. The dimension of the green sheets was not changed by the extraction of the polystyrene microspheres. Ceramic foam with spherical pores could be obtained by the heat treatment of the green sheets after extracting the polystyrene microspheres. Linear shrinkage of the sheets observed in the heat treatment was $20 \%$.

[Received January 21, 1997; Accepted April 1, 1997]
\end{abstract}

Key-words : Sr-alkoxide, Ti-alkoxide, Suspension, Ceramic foam, Polymer extraction

\section{1. 緒言}

最近，エレクトロニクスセラミックスの軽量化が電子機器の 可搬性, マンマシンインターフェイスの観点から注目を集めて いる，軽量化を達成する方法の一つが部材のフォーム化であ る.また, 材料のフォーム化は, 軽量化だけでなく, 材料本来 の特性に加えて断熱性, 低誘電性, 物質輸送経路形成などの新 たな特性を付与することができ，この面でも新しい応用分野の 開拓が期待できる. しかし, セラミックス材料に積極的に気孔 を導入し，その大きさ，形状，分散状態などを制御してセラ ミックフォームを作製する試みは，あまり行われていな (1) 4). 本研究はセラミックス部材の制御されたフォーム化 を実現する方法としてグリーンシート中に分散された高分子マ イクロ球の溶解抽出による方法を評価したものである。溶解抽 出の対象となる高分子マイクロ球が小さくなるとグリーンシー 卜を構成する原料粒子径を小さくすることが要求されるが，金 属アルコキシドから誘導された微粒子は, 粒径 $10 \mathrm{~nm}$ 程度の 非常に微細な粒子で5)，この目的によく合致したものである。 金属アルコキシドは, 加水分解により多くの場合,「金属酸化 物微粒子」あるいは「金属酸化物前駆体微粒子」として析出す る. 近年, これらの微粒子はさまざまなセラミックスの原料と して検討が行われ, そのいくつかはゾルーゲルガラス原料, 乾 式原料として工業的に利用されるようになっている. 本研究で は金属アルコキシドから合成した $\mathrm{SrTiO}_{3}$ 微粒子を使用して フォーム作製を行った。 また, 合成粒子の熱的挙動や凝集状態 などの特性付けも行った.

\section{2. 実験概要}

フォームの作製は次の三つのステップで行った。まず，スラ リー中に高分子マイクロ球を分散してグリーンシートを形成す る. 次に得られたグリーンシート中の高分子マイクロ球を溶媒 を用いて溶解抽出する.この高分子マイクロ球抽出後のグリー ンシートを熱処理してセラミックフォームを得る。この作製プ
ロセ入に扔いては，高分子マイクロ球の素材となる高分子に対 し，「マイクロ球の合成が可能であること」(6) 8) と「溶媒によ る抽出性がよいこと」が要求される．このような条件を満たす 高分子として本実験ではベンゼン，トルエンなどの有機溶媒に 容易に溶解するポリスチレンを選んだ。また，シート成形のた めに添加するバインダー高分子は，「マイクロ球の素材の高分 子の溶媒には溶解や膨潤を受けず」，なた逆に「シート成形の ための溶媒が高分子マイクロ球を溶解しない」という条件を満 たす必要がある。本実験ではこのような高分子として水溶性の ポリビニルアルコール (PVA) を用いた。したがって， $\mathrm{SrTiO}_{3}$ 微粒子サスペンションは水系サスペンションとした。

\section{3. 実 験}

$3.1 \mathrm{SrTiO}_{3}$ 微粒子一水系サスペンションの調製

金属 $\mathrm{Sr}$ を, イソプロピルアルコールと $82^{\circ} \mathrm{C} て ゙ 1 \mathrm{~h}$ かくはん 還流下反応させ，金属濃度 $0.3 \mathrm{M}$ の $\mathrm{Sr}\left(\mathrm{OC}_{3} \mathrm{H}_{7}{ }^{i}\right)_{2}$ イソプロピル アルコール溶液を調製した。この溶液へ金属比が $\mathrm{Sr} / \mathrm{Ti}=1 / 1$ となるように $\mathrm{Ti}\left(\mathrm{OC}_{3} \mathrm{H}_{7}\right)_{4}$ を加え，更に1h かくはん還流を 行った。調製された $\mathrm{Sr}\left(\mathrm{OC}_{3} \mathrm{H}_{7}{ }^{i}\right)_{2}-\mathrm{Ti}\left(\mathrm{OC}_{3} \mathrm{H}_{7}{ }^{i}\right)_{4}$ 混合イソプロピ ルアルコール溶液に, 化学量論量の 15 倍の $100^{\circ} \mathrm{C}$ 水を加え て加水分解し, 更に1h かくはん還流を行った。得られた $\mathrm{SrTiO}_{3}$ 微粒子のサスペンションから未反応のイソプロピルア ルコールをドレン管を用いて留去しながら，分散媒をイソプロ ピルアルコールから水へ置換した. 水への置換完了は, 分散媒

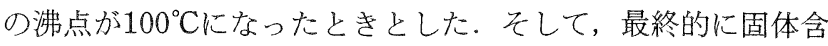
有量 $0.1 \mathrm{~g} \cdot \mathrm{ml}^{-1}$ の $\mathrm{SrTiO}_{3}$ 微粒子一水系サスペンションを調製 した. 以上の操作のフローシートを図 1 に示す.

得られた $\mathrm{SrTiO}_{3}$ 微粒子については, ピクノメーターによる 密度測定, 固体合有量 $0.03 \mathrm{~g} \cdot \mathrm{ml}^{-1}$ に希釈した水系サスペン ションを同体積のベンゼンと混合し，微粒子がどちらの相に移 動するかを観察して微粒子の極性を判定するフラッシング試 験9), X 線回折分析（XRD; マックサイエン久製, MXP 3VA), 


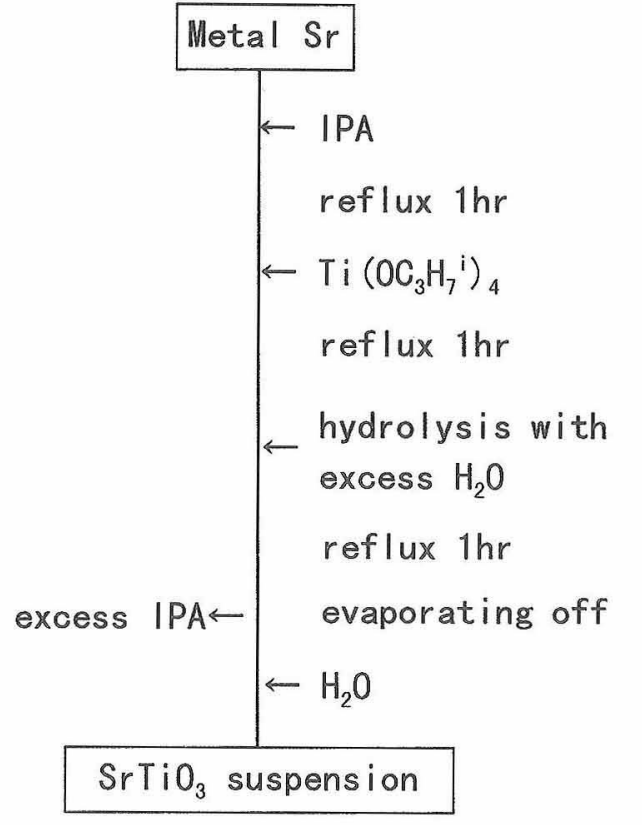

* IPA=isopropyl alcohol

Fig. 1. Preparation of the $\mathrm{SrTiO}_{3}$ suspension.

TG-DTA 分析（リガク製，TAS-100），透過型電子顕微鏡観 察（TEM；日本電子製，JEM-100CX II），走査型電子影微鏡 観察（SEM; 日本電気製，JSM-25S），実体顕微鏡観察（ニコ ン製，SMZ-10-1）を行った。

\section{2 ポリスチレン球の調製}

15 mass\%ポリスチレンーベンゼン溶液 $50 \mathrm{ml}$ を, 旭電化工業 製，非イオン界面活性剤 OEG-106の4.8 mass\%水溶液 $420 \mathrm{ml}$ に加え，ホモジナイザーにより乳化・分散させた。この系を室

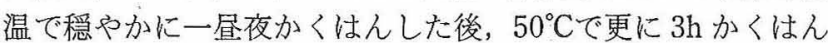
することにより，水中に分散したポリスチレンーベンゼン溶液 の液滴からベンゼンを除去して乾燥させ，ポリスチレンマイク 口球を得た。ここで，非イオン界面活性剂を水に添加するの は，乾燥過程で水に分散したポリスチレンーベンゼン溶液の液 滴が合一して，ポリスチレンマイクロ球の収率を低下させるこ とを防ぐためである. 得られたポリスチレンマイクロ球につい ては，SEM 観察を行い，その粒度分布を調べた。

\section{3 セラミックフォームの作製}

3.1節で調製した $\mathrm{SrTiO}_{3}$ 微粒子一水系サスペソション $15 \mathrm{ml}$ に, バインダーとして PVA を $\mathrm{SrTiO}_{3}$ 重量の 8 mass\%, 3.2節 で調製したポリスチレンマイクロ球を $\mathrm{SrTiO}_{3}$ 重量の60 mass\%添加しかくはん混合した後, 濃縮してスラリーとした。 これを直径 $85 \mathrm{~mm}$ の型に鋳込み, 室温で $3 \mathrm{~d}$ 乾燥してグリー ソシートを得た.このグリーンシートからポリスチレンマイク 口球を溶解抽出した，溶解抽出にはソックスレ一抽出器を用 い, ベンゼン $150 \mathrm{ml}$ を抽出溶媒として, $60^{\circ} \mathrm{C} て ゙ 5 \mathrm{~h}$ 抽出した. 抽出後, $1^{\circ} \mathrm{C} \cdot \mathrm{min}^{-1}$ の速度で $600^{\circ} \mathrm{C}$ をで昇温して $1 \mathrm{~h}$ 保持し， 更に $2{ }^{\circ} \mathrm{C} \cdot \min ^{-1}$ の速度で $1000^{\circ} \mathrm{C}$ ま昇温し $2 \mathrm{~h}$ 保持してセラ ミックフォームを得た，得られたグリーンシートやセラミック フォームについて SEM 観察及び TG-DTA 分析を行った。

\section{4. $1 \mathrm{SrTiO}_{3}$ 微粒子}

\section{4. 結果及び考察}

$\mathrm{Sr}\left(\mathrm{OC}_{3} \mathrm{H}_{7}{ }^{i}\right)_{2}$ と $\mathrm{Ti}\left(\mathrm{OC}_{3} \mathrm{H}_{7}{ }^{i}\right)_{4}$ の混合イソプロピルアルコール 溶液のかくはん還流下, 熱水による加水分解によって得られる
微粒子は, 図 2 の粉末 X 線回折分析の結果に示すように, 結 晶性の $\mathrm{Sr}^{\top} \mathrm{TiO}_{3}$ 微粒子であった。 熱処理温度が $700^{\circ} \mathrm{C}$ より低温 側ではその回折線のピーク強度に变化はみられなかったが, 高 温側では, 蓺処理温度の増加に伴って増加する傾向が見られ た.

この $\mathrm{SrTiO}_{3}$ 微粒子の 1 次粒子は, TEM 観察によると, 直 線的な辺をもつ正六角形に近い板状粒子であり，その粒径は $20 \mathrm{~nm}$ 程度であった（図 3). 観察される粒子には，六角形か ら変形しているものや，いくつかの六角板状粒子が一体化して いるものも見られた．水ーベンゼン系でフラッシング試験を 行ったところ, 水中に分散している微粒子はベンゼン相には移 行せず，金属アルコキシドから合成された $\mathrm{SrTiO}_{3}$ 微粒子は親 水性であった. ピクノメーターを用いた密度測定の結果, 本 実験で得られた $\mathrm{SrTiO}_{3}$ 敒粒子の密度は $4.45 \mathrm{~g} \cdot \mathrm{cm}^{-3}$ で岁り (表 1)，一般に知られている格子サイズから算出される $\mathrm{SrTiO}_{3}$ の真密度 $5.116 \mathrm{~g} \cdot \mathrm{cm}^{-3}$ と比較すると $13 \%$ 程度低い密度 となっていた.

$80^{\circ} \mathrm{C}$ で乾燥した $\mathrm{SrTiO}_{3}$ 微粒子を, $20^{\circ} \mathrm{C} \cdot \mathrm{min}^{-1}$ の昇温速度 で室温から $1200^{\circ} \mathrm{C}$ 至で TG-DTA 分析を行った結果を図 4 に示 す.この図から分かるように金属アルコキシドから合成された

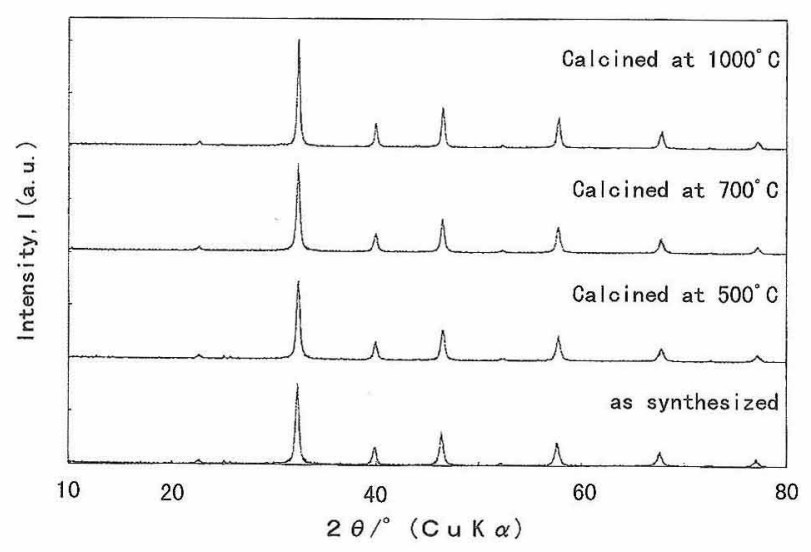

Fig. 2. X-ray diffraction patterns of the $\mathrm{SrTiO}_{3}$ powder prepared from the metal alkoxides.

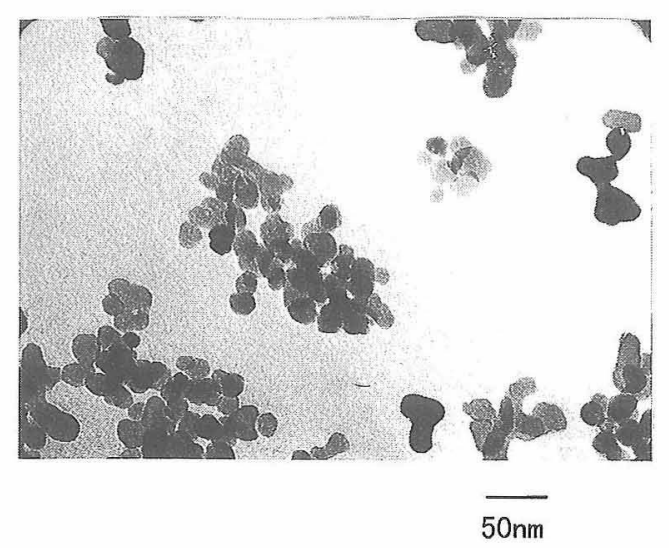

Fig. 3. Transmission electron micrograph of the $\mathrm{SrTiO}_{3}$ particles obtained by hydrolyzing the $\mathrm{Sr} / \mathrm{Ti}$ mixed alkoxides.

Table 1. Density of $\mathrm{SrTiO}_{3}$ Particles Obtained by Hydrolysis of $\mathrm{Sr} / \mathrm{Ti}$ Mixed Alkoxides

\begin{tabular}{ccccccc}
\hline Sample number & 1 & 2 & 3 & 4 & 5 & average \\
\hline Density $/ \mathrm{g}^{\prime} \mathrm{cm}^{-3}$ & 4.41 & 4.49 & 4.49 & 4.41 & 4.44 & 4.45 \\
\hline
\end{tabular}




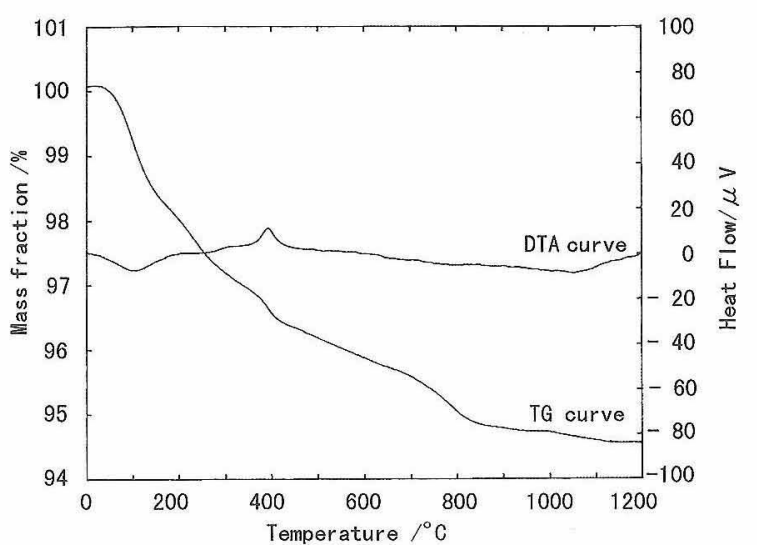

Fig. 4. TG-DTA curves of the $\mathrm{SrTiO}_{3}$ powder prepared from the metal alkoxides.

$\mathrm{SrTiO}_{3}$ の重量は, $850^{\circ} \mathrm{C}$ までで約 $5 \%$ 減少し，それ以降では ほぼ一定となった。なた，DTA曲線には， $100^{\circ} \mathrm{C}$ 付近に吸熱 ピーク， $400^{\circ} \mathrm{C}$ 付近に発熱ピークが見られ，これらのピーク付 近では重量の減少率はやや大きくなっていた. $100^{\circ} \mathrm{C}$ 付近の吸 熱ピークは, $\mathrm{SrTiO}_{3}$ 微粒子表面に吸着している水や溶媒の脱 着によるものであり， $400^{\circ} \mathrm{C}$ 付近の発熱ピークは，溶媒の熱分 解により生成した無定形炭素の燃烓によるものと思われる.

\section{2 ポリスチレンマイクロ球}

本実験で得られたポリスチレンマイクロ球のSEM 写真を 図 5 に示す。なた，図 6 に球の粒度分布を示す。図 5 よりポ リスチレンマイクロ球は，ほほ真球で，球表面に合成時の球相 互の衝突により形成されたと考えられるわずかなへこみを有す るものも見られた。. 球は $15 \sim 20 \mu \mathrm{m}$ に粒径分布のピークを持 ち, 約 $75 \%$ の球が $5 \sim 25 \mu \mathrm{m}$ の範囲に存在している. したがっ て, セラミックフォームには, 球の粒径と同程度の直径を持つ 球状気孔ができると期待される。

4.3 セラミックフォーム

図 7 (a), (b), (c)k本実験で得られたポリ久チレンマイクロ

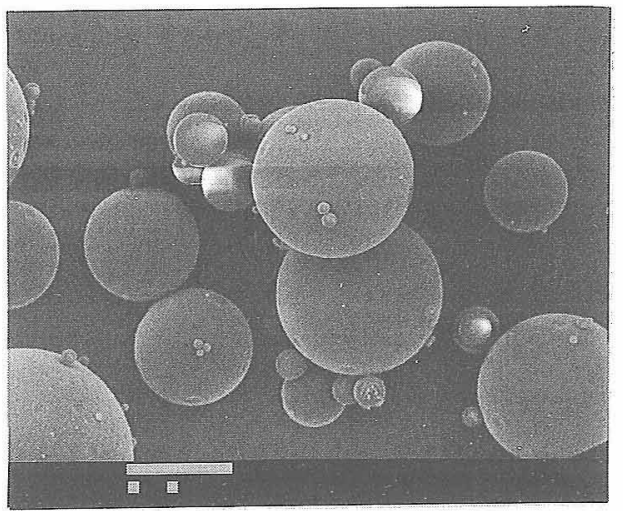

$10 \mu \mathrm{m}$

Fig. 5. Scanning electron micrograph of the polystyrene microspheres.

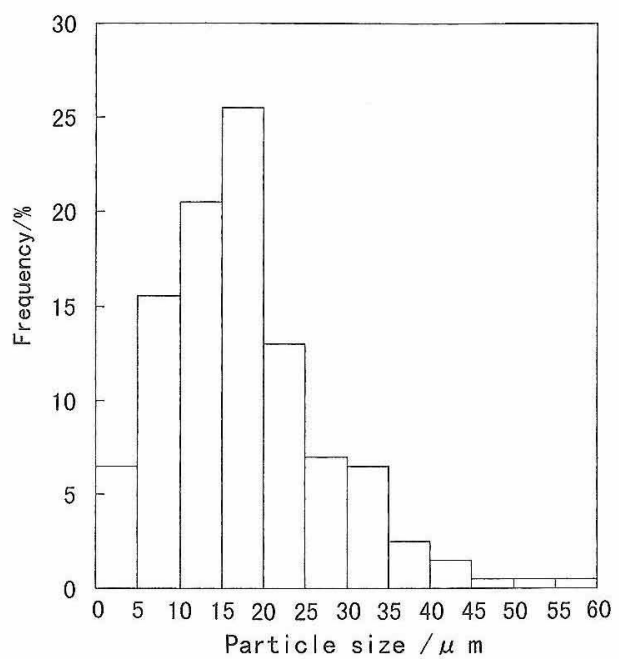

Fig. 6. Particle size distribution of the polystyrene microspheres.

球抽出前のグリーンシート，ポリスチレンマイクロ球抽出後の グリーンシート，これを $1000^{\circ} \mathrm{C} て ゙$ 熱処理して得られたセラ ミックフォームの SEM 写真を示す。 \&た，表 2 に，それぞれ の処理に伴うグリーンシートの收縮率を示す. 図 7 (a)加ら分 かるように, 溶解抽出前のグリーンシートは, ポリスチレンマ イクロ球が $\mathrm{SrTiO}_{3}$ 微粒子のマトリックス相に埋め込悉れた構 造となっていた。 $\mathrm{SrTiO}_{3}$ 微粒子マトリック久相は, 粒径 3 $\mu \mathrm{m}$ から $10 \mu \mathrm{m}$ 程度の凝集粒子で構成されていた、ソックス レー抽出器を用いたベンゼソによるポリスチレンマイクロ球の 溶解抽出は，図７(b)加ら分加るように良く達成されており， ポリスチレンマイクロ球の形状は球状気孔としてポリスチレン マイクロ球抽出後のグリーンシート内に良く残されていた。し かし, 本実験で使用したポリスチレンマイクロ球に含まれる直 径 $5 \mu \mathrm{m}$ 以下の球に由来する気孔は, 岁可明暸な球形状にな らなかった。これらの直径 $5 \mu \mathrm{m}$ 以下のポリスチレンマイクロ 球は, グリーンシートのマトリックス相を形成する $\mathrm{SrTiO}_{3}$ 微 粒子の凝集粒子と同程度かそれ以下の大きさであり，マトリッ クス相の PVA 中に取り込まれ, グリーンシート中で明瞭に観 察されなかった。ベンゼンによるポリスチレンマイクロ球の抽 出処理に伴うグリーンシートの寸法変化は, 表 2 に示したよ うに全く見られず，PVAは，有機溶媒に対して極めて安定で あり，本実験のようなプロセスに適したバインダーであること を示している. ポリスチレンマイクロ球によってグリーンシー 卜内に形成された球状気孔は, 四7 (c) 加分かるように $1000^{\circ} \mathrm{C}$ 熱処理後にもシート内に保持され, 球状気孔を有す るセラミックフォームを作製することができた． $1000^{\circ} \mathrm{C}$ 熱 処理に伴うシート寸法の収縮率は表 2 に示すように約 $20 \%$ で あった。

図 8 に, ポリスチレンマイクロ球抽出後のグリーンシートを $20^{\circ} \mathrm{C} \cdot \mathrm{min}^{-1}$ の速度で $1200^{\circ} \mathrm{C}$ で昇温して測定した TG-DTA 曲線を示す. 図より, ポリスチレンマイクロ球抽出後のグリー ンシートには， $1200^{\circ} \mathrm{C}$ なの熱処理により，約 $17 \%$ の重量減 が見られた。香た, 本実験て使用したPVAは, 図 9 に示すよ

Table 2. Linear Shrinkage of the Green Sheets

\begin{tabular}{lcccccc}
\hline \multirow{2}{*}{ Linear shrinkage $/ \%$} & \multicolumn{5}{c}{ Sample number } \\
\cline { 2 - 7 } & 1 & 2 & 3 & 4 & 5 & Average \\
\hline After extraction process & 0.00 & 0.00 & 0.00 & 0.00 & 0.00 & 0.00 \\
\hline After heat-treatment at $1000^{\circ} \mathrm{C}$ & 20.1 & 20.0 & 21.3 & 20.3 & 20.2 & 20.4 \\
\hline
\end{tabular}




\section{(appearance)}

(a)

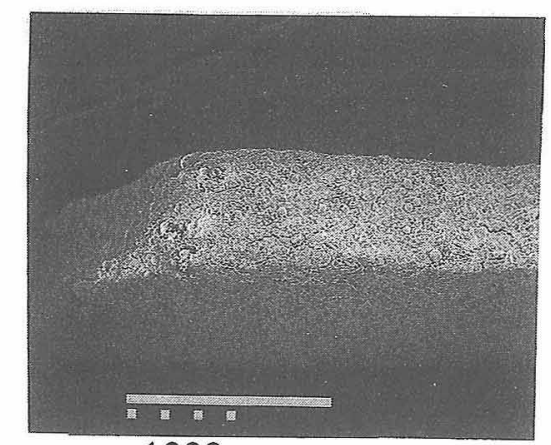

$1000 \mu \mathrm{m}$

(b)

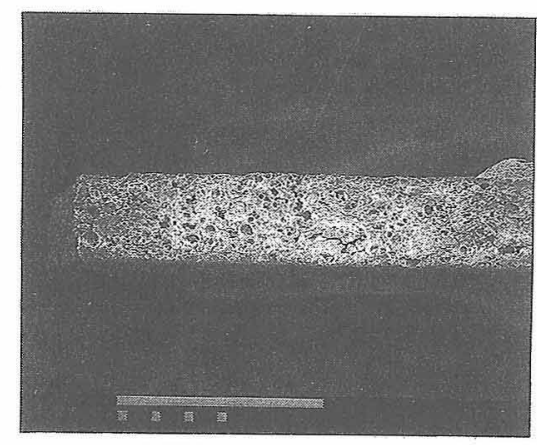

$1000 \mu \mathrm{m}$

(c)

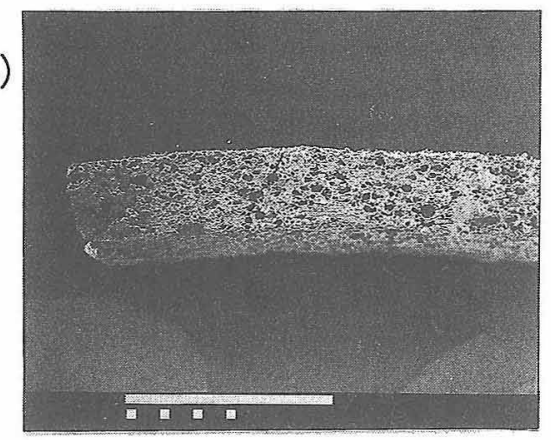

$1000 \mu \mathrm{m}$ (cross section)

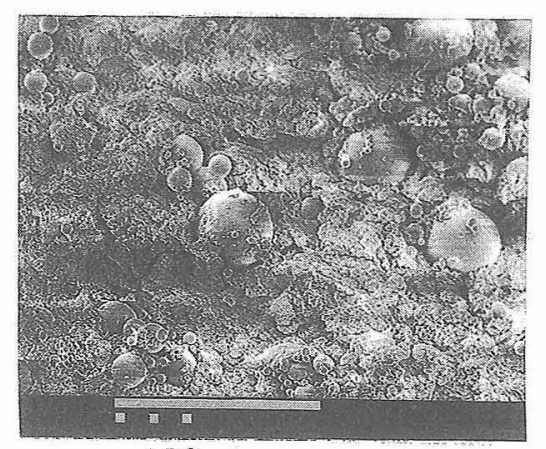

$100 \mu \mathrm{m}$

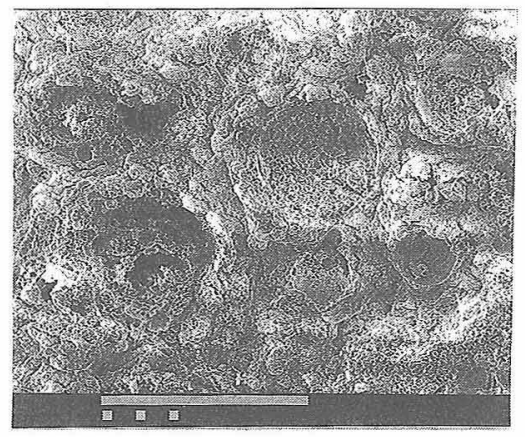

$100 \mu \mathrm{m}$

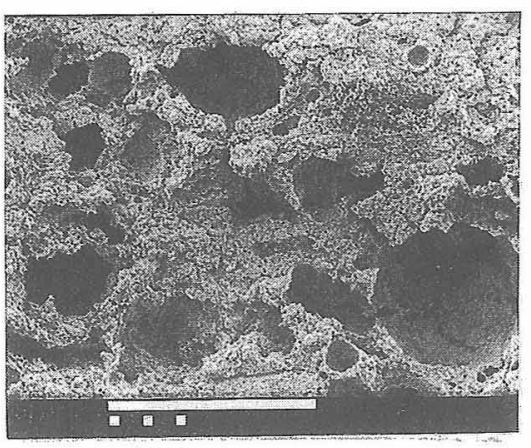

$100 \mu \mathrm{m}$

Fig. 7. Scanning electron micrographs of the green sheets and the $\mathrm{SrTiO}_{3}$ foams. (a) Green sheet (before extraction of the polystyrene microspheres), (b) green sheet (after extraction of the polystyrene microsphrers), (c) $\mathrm{SrTiO}_{3}$ foam (heat-treated at $1000^{\circ} \mathrm{C}$ ).

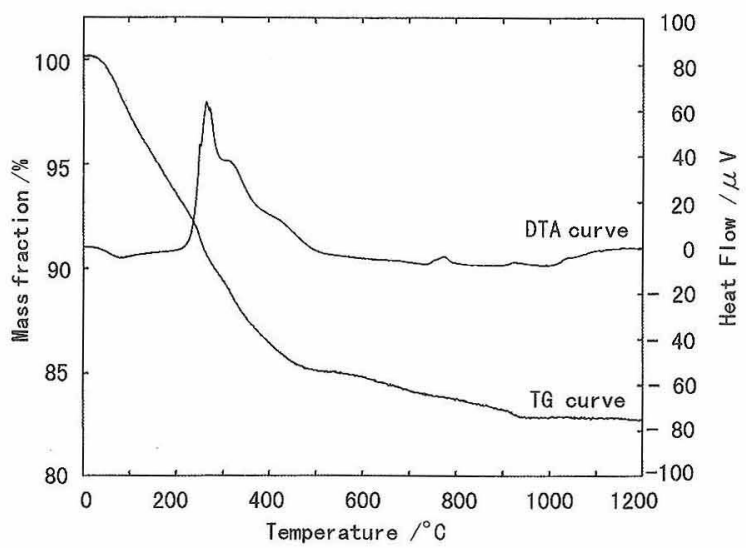

Fig. 8. TG-DTA curves of the green sheet measured after the extraction of the polystyrene microspheres.

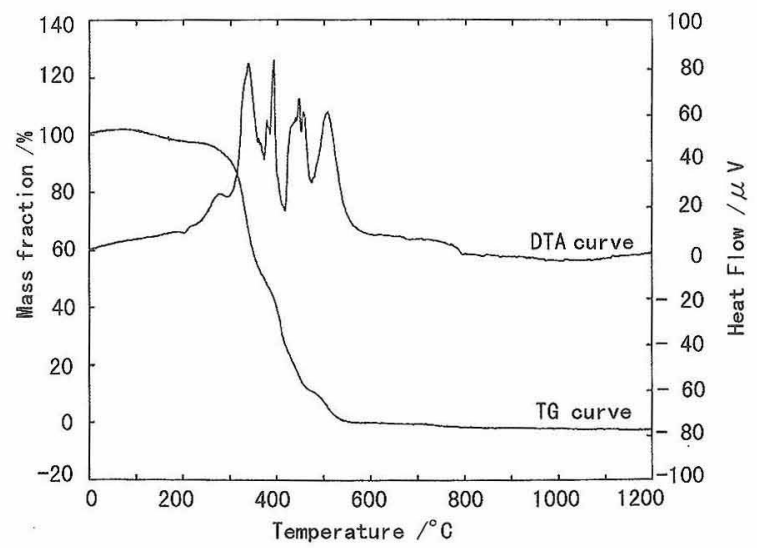

Fig. 9. TG-DTA curves of the PVA binder. 


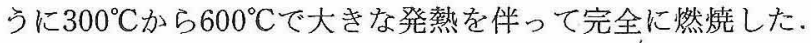
$\mathrm{SrTiO}_{3}$ 微粒子の $1200^{\circ} \mathrm{C} て ゙ の$ 熱処理に伴う重量減は，4.1節で 述べたように約 $5 \%$ \%゙り，グリーンシートに添加されてい る $\mathrm{PVA}$ は， $\mathrm{SrTiO}_{3}$ 微粒子の 8 mass\%なので，これらの $\mathrm{SrTiO}_{3}$ 微粒子と PVA で構成されているグリーンシートの熱 処理に伴う重量減は，約 $12 \%$ であると考えられる.実際のグ リーンシートの重量減が，前述のように予想される重量減より 大きくなるのは，PVAに取り込まれグリーンシート中から溶 解抽出することができなかった残留ポリスチレンが, 熱処理に より焼失するためであると考えられる。なた，ポリスチレンマ イクロ球抽出後のグリーンシートの DTA 曲線には, $100^{\circ} \mathrm{C}$ 付 近に吸熱のピークと $300^{\circ} \mathrm{C}$ か $5400^{\circ} \mathrm{C}$ 付近に大きな発熱のピー クが見られた（図 8). $100^{\circ} \mathrm{C}$ 付近の吸熱のピークは， $\mathrm{SrTiO}_{3}$ 微 粒子のDTA 曲線（図 4) と同様に水や有機溶媒の脱着による ものであり，300 $\mathrm{C}$ か $400^{\circ} \mathrm{C}$ 付近の大きな発熱ピークは, 主 にPVAの燃焼に由来するものと考えられる。

\section{4 サスペンション中の凝集粒子}

グリーンシートからのポリマーの溶解抽出により形状制御さ れた気孔を有するセラミックフォームが作製できるが，気孔の 最小径はグリーンシートのマトリックス相を形成する凝集粒子 径によって制限されることを明らかにした，実験で使用した $\mathrm{SrTiO}_{3}$ 微粒子-水系サスペンションの実体顕微鏡観察 (80倍) によると, 固体含有率 $0.1 \mathrm{~g} \cdot \mathrm{ml}^{-1} の \mathrm{SrTiO}_{3}$ 微粒子一水系サ久 ペンショョン中では， $\mathrm{SrTiO}_{3}$ は，ほぼ均一な大きさの粒子とし て水中に分散している状態が観察された。図10(a)，(b)は，こ のような粒子が単一粒子として存在している状態と，それらが 凝集して存在している状態を実体顕微鏡によって確認しながら 乾燥してスライドグラス上に固定し，撮影したSEM 写真であ る。図10(a)加ら分加るように $\mathrm{SrTiO}_{3}$ 微粒子一水系サスペン

(a)

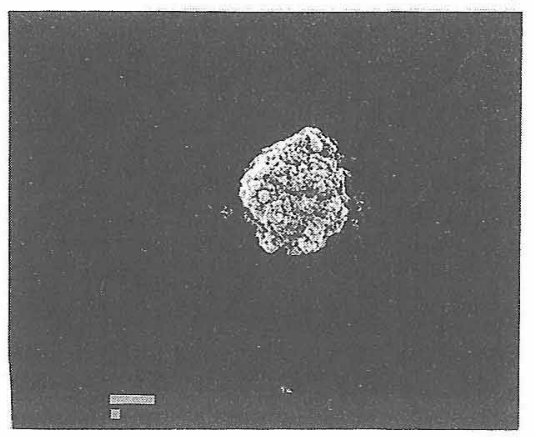

$1 \mu \mathrm{m}$

(b)

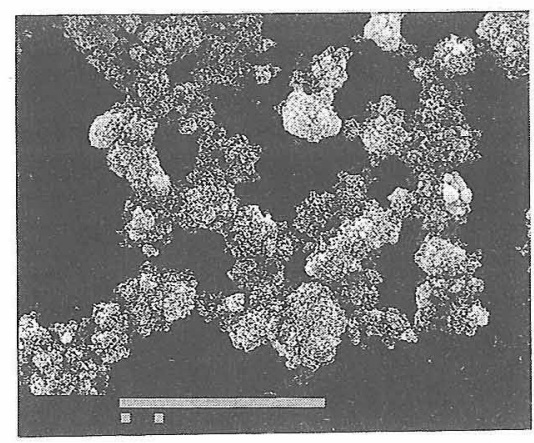

$10 \mu \mathrm{m}$

Fig. 10. Scanning electron micrographs of the $\mathrm{SrTiO}_{3}$ aggregates. (a) Secondary aggregates, (b) packing structure of the secondary aggregates.
ション中にみられる粒子は, 粒径が $3 \mu \mathrm{m}$ 程度でほぼ球形の粒 子であり，0.1 $\mu \mathrm{m}$ 程度の更に細かい粒子で構成された凝集粒 子であった４.1節で述べたように，金属アルコキシドから合 成された $\mathrm{SrTiO}_{3}$ 微粒子の 1 次粒子径が $20 \mathrm{~nm}$ 程度であったこ とを考慮すると，この $0.1 \mu \mathrm{m}$ 程度の粒子もまた， $20 \mathrm{~nm}$ 程度 の 1 次粒子が凝集して形成された凝集粒子と考えられる。こ れらの凝集粒子を区別するために，以下では，金属アルコキシ ドの加水分解によって生じた 1 次粒子が凝集して形成される $0.1 \mu \mathrm{m}$ 程度の粒子を 1 次凝集粒子，この 1 次凝集粒子が凝集 して形成される $3 \mu \mathrm{m}$ 程度の粒子を 2 次凝集粒子と呼ぶことに する。 2 次凝集粒子は，サスペンションを希釈しても更に細か く分散することはなかった。なた，サスペンションが濃縮さ れ, 凝集粒子間距離が減少すると 2 次凝集粒子は互いに凝集 して図10(b)に見られるような粗い網目状構造を形成した。こ の絪目状構造内に打いて, 個々の 2 次㠜集粒子の境界は明瞭 ではなく，いくつかの2 次凝集粒子が密着して存在している 部分では，それらの 2 次凝集粒子が一体化して一つの大きな 凝集粒子であるように観察された。このような網目状構造は, サスペンションの流動やかくはんにより容易に壞された，上記 のようなサスペンションの顕微鏡観察の結果をもとに, グリー ンシートのマトリックス相を形成する凝集粒子とサ久ペソショ ン中の㠜集粒子を比較すると,グリーンシートのマトリックス 相を形成する粒径 $3 \mu \mathrm{m}$ から $10 \mu \mathrm{m}$ の凝集粒子は, サスペン ション中の粒径 $3 \mu \mathrm{m}$ 程度の 2 次凝集粒子とそれらが形成する 網目状構造に由来するものであると考えられる，なた，固体含 有率 $0.1 \mathrm{~g} \cdot \mathrm{ml}^{-1}$ の $\mathrm{SrTiO}_{3}$ 微粒子一水系サスペソション $50 \mathrm{ml}$ を, 高さ $145 \mathrm{~mm}$ の沈降管に入れ, よくかくはんして分散した 後静置し, 上澄內と懸濁層の界面の移動速度を観察した結果, 界面の移動速度 $V$ は7.9 $\times 10^{-4} \mathrm{~cm} \cdot \mathrm{s}^{-1}$ であり, 最終的な沈降 体積は24 $\mathrm{cm}^{3}$ (図11) であった. 上記の顕微鏡観察による 2 次 凝集粒子径 $(d) \sim 3 \mu \mathrm{m}$ と, この 2 次凝集粒子の沈降速度 $V=7.9 \times 10^{-1} \mathrm{~cm} \cdot \mathrm{s}^{-1}$ 加ら Stokes 式（(1)式）を用いて2 次 凝集粒子密度 $\rho_{\mathrm{sa}}$ を求めると $\rho_{\mathrm{sa}}=2.6 \mathrm{~g} \cdot \mathrm{cm}^{-3}$ であった10).

$$
V=1 / 18 \times\left(\rho_{\mathrm{sa}}-\rho_{0}\right) g d^{2} / \eta_{0}
$$

なお, 計算には水の密度 $\rho_{0}=0.998206 \mathrm{~g} \cdot \mathrm{cm}^{-3}$, 水の粘度 $\eta_{0}$ $=1.0020 \mathrm{mPa} \cdot \mathrm{s}$, 重力加速度 $\mathrm{g}=981 \mathrm{~cm} \cdot \mathrm{s}^{-2}$ を使用した。 し たがって, 1 次粒子密度として4.1節で求めた $\mathrm{SrTiO}_{3}$ 微粒子密 (a)

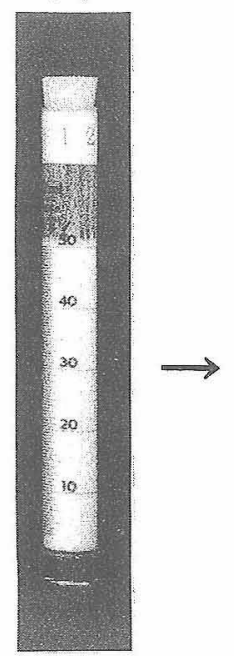

(b)

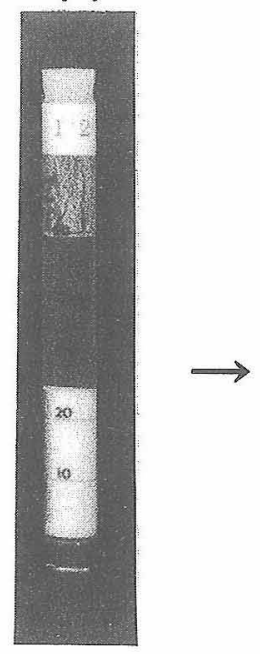

(c)

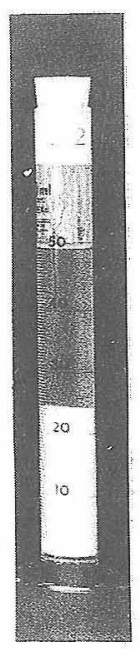

Fig. 11. Sedimentation test for the $\mathrm{SrTiO}_{3}$ suspensions. (a) Immediately after dispersion, (b) after $18 \mathrm{~h}$, (c) after $72 \mathrm{~h}$. 
度の実験值 $\rho_{\mathrm{s}}=4.45 \mathrm{~g} \cdot \mathrm{cm}^{-3}$ を使用すると 2 次凝集粒子中の含 水率は $53 \mathrm{vol} \%$ となり，1次凝集粒子がかなり粗く充填された 状態であることが分かる。そして, $\mathrm{SrTiO}_{3}$ 微粒子密度 $\rho_{\mathrm{s}}$ $=4.45 \mathrm{~g} \cdot \mathrm{cm}^{-3}$ 加計算される固体含有率 $0.1 \mathrm{~g} \cdot \mathrm{ml}^{-1}$ の开久 ペンション $50 \mathrm{ml}$ 中の $\mathrm{SrTiO}_{3}$ 微粒子の体積は $1.12 \mathrm{~cm}^{3}$ (体積

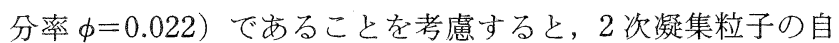
由沈降によって生じる 3 次元網目状構造の空隙率はその沈降 体積 $24 \mathrm{~cm}^{3}$ より $95 \mathrm{vol} \%$ となる. 2 次凝集粒子に打けるこの空 隙はグリーンシートに抢けるポリスチレン球やバインダーの PVAのポケットとなるものである。以上の沈降実験の結果か らポリスチレンマイクロ球によって形成される気孔を微細化す るためには，サスペンション中の 2 次凝集粒子及びそれらが 形成する網目状構造の孔を微細化する必要がある。本実験では 直径 $5 \mu \mathrm{m}$ 以下のポリスチレンマイクロ球に由来するような気 孔の形状制御が困難であったが, 直径 $5 \mu \mathrm{m}$ 以下のポリスチレ ンマイクロ球に由来するようなより微細な気孔形成を行い, 精 密なセラミックフォーム作製を行うためには, 金属アルコキシ ド由来の $\mathrm{SrTiO}_{3}$ 微粒子の分散を改善する必要があると結論で きる。

\section{5. 結 論}

$\mathrm{SrTiO}_{3}$ 微粒子を金属アルコキシドの加水分解により合成し， その微粒子の特性付けを行った。そして, この微粒子を用いて 作製したグリーンシートからポリマーを溶解抽出することによ りセラミックフォームの作製を試み，次の結果を得た。

(1) 金属アルコキシド由来の $\mathrm{SrTiO}_{3}$ 微粒子一水系サ久ペン ションにシート形成のためのバインダーとしてPVAを，また 球状気孔を導入のための高分子マイクロ球としてポリスチレン マイクロ球を添加して作製したグリーンシートは, ポリスチレ ンマイクロ球が粒径 $3 \mu \mathrm{m}$ から $10 \mu \mathrm{m}$ 程度の凝集粒子によって 形成される $\mathrm{SrTiO}_{3}$ 微粒子マトリックス相に埋め込まれた構造 であった。

（2）グリーンシート中のポリスチレンマイクロ球は溶解抽 出により容易に除去され，グリーンシートにはそれらの球に対
応する球状気孔が形成された。溶解抽出に伴う，グリーンシー トの寸法変化は見られず，バインダーとして添加したPVA は 気孔形状をよく保持していた。しかし，マトリックス相を形成 する凝集粒子より小さいポリスチレンマイクロ球に由来する気 孔は, 明瞭な球形にならなかった。

（3）ポリスチレンマイクロ球によりグリーンシート内に形 成された球状気孔は， $1000^{\circ} \mathrm{C}$ 熱処理後にも崩壊することな くシート内に保持され, 球状気孔を有するセラミックフォーム を形成することができた。

（4）金属アルコキシド由来の $\mathrm{SrTiO}_{3}$ 微粒子は，水系妆 ペンション中に拈いて $20 \mathrm{~nm}$ 程度の粒径の 1 次粒子が, 3 段階 の凝集構造を形成し, 粗い充填状態になっていた.グリーン シートのマトリックス相は，このような金属アルコキシド微粒 子の多段階の凝集構造と充填状態を反映して形成される. した がって，本プロセスにより，より微細な気孔を有するセラミッ クフォームを精密に作製するためには $\mathrm{SrTiO}_{3}$ 微粒子の分散状 態の改善が必要である。

\section{文献}

1) L. J. Gibson and M. F. Ashby, "Cellular Solids Structure and Properties," Pergamon Press (1988) pp. 150-53.

2）尾崎義治，日本セラミックス協会関東支部講習会資料 (1993) pp. 21-33.

3）加納 睦, 橋場 稔, 塗師幸男, 日本セラミックス協会年会 講演予稿集 (1990) p. 607.

4）川崎兼司, 尾崎義治, 日本セラミックス協会年会予稿集 (1992) p. 18.

5）笠井紀宏, 尾崎義治, 山本章造, 窒協, 95, 1000-06 (1987).

6) 近藤保, 小石真純, “マイクロカプセル”, 三共出版 (1984) pp. 63-65.

7）近藤 保, “マイクロカプセル”, 共立出版（1985）pp. 4-16.

8）近藤 保, 鈴木四郎, “生活の界面科学”, 三共出版 (1991) pp. 191-201.

9） T. C. Patton, 植木憲二監訳, “塗料の流動と顔料分散”, 共 立出版 (1981) pp. 189-90.

10）渡辺信淳, 渡辺 昌, 玉井康勝, “表面㧍よび界面”, 共立出 版 (1981) pp. 145-76. 